\title{
Closed-loop hydrometallurgical treatment of end-of-life lithium ion batteries: Towards zero-waste process and metal recycling in advanced batteries
}

\author{
Thomas Abo Atia ${ }^{\mathrm{a}, \mathrm{b}}$, Giuseppe Elia ${ }^{\mathrm{c}}$, Robert Hahn ${ }^{\mathrm{d}}$, Pietro Altimari ${ }^{\mathrm{a}}$, Francesca Pagnanelli, ${ }^{\mathrm{a},}$ \\ ${ }^{a}$ Department of Chemistry, Sapienza University of Rome, Rome 00185, Italy \\ ${ }^{\mathrm{b}}$ Waste Recycling Technologies, Flemish Institute for Technological Research, Mol 2400, Belgium \\ (current position) \\ c Technische Universität Berlin, Research Center of Microperipheric Technologies, Berlin D- \\ 13355, Germany \\ ${ }^{\mathrm{d}}$ Fraunhofer-Institut für Zuverlässigkeit und Mikrointegration, Berlin D-13355, Germany
}

\begin{abstract}
This work presents an enhanced hydrometallurgical process for recycling lithium ion batteries. First, end-of-life batteries were processed in a physical pre-treatment plant to obtain a representative electrode material. The resulting leachate was purified forth by iron-precipitation, liquid-liquid extractions, and an innovative $\mathrm{Li}-\mathrm{Na}$ separation, in order to obtain valuable products. These products include high-grade graphite, cobalt oxide $\left(\mathrm{Co}_{3} \mathrm{O}_{4}\right.$, purity $\left.83 \%\right)$, cobalt oxalate $\left(\mathrm{CoC}_{2} \mathrm{O}_{4}\right.$, purity 96\%), nickel oxide ( $\mathrm{NiO}$, purity $89 \%$ ), and lithium carbonate $\left(\mathrm{Li}_{2} \mathrm{CO}_{3}\right.$, purity $99.8 \%$ ). The recovery rate was quantitative for graphite, between $80 \%$ and $85 \%$ for cobalt depending on the nature of the recovery method, $90 \%$ for nickel, and $72 \%$ for lithium. Secondary streams were also valorized to obtain sodium sulfate $\left(\mathrm{Na}_{2} \mathrm{SO}_{4}\right.$, purity $\left.96 \%\right)$, and $\mathrm{MnCoFe}_{2} \mathrm{O}_{4}$ magnetic nano-sorbents according to the zero-waste concept. In order to close the loop, recycled $\mathrm{Co}_{3} \mathrm{O}_{4}$ and $\mathrm{NiO}$ were used as conversion-type anode materials for advanced lithium ion batteries showing promising performances.
\end{abstract}

Keywords: LIB recycling; Graphite; Cobalt; Nickel; Lithium; Advanced LIB

* Corresponding author.

E-mail address: francesca.pagnanelli@uniroma1.it (F. Pagnanelli).

\section{Introduction}

The challenges for large scale exploitation of hydrometallurgical recycling processes of lithium ion batteries (LIB) mainly rely on sustainability. Main issues concern with the efficiency and safety of pre-treatments, the intricate scale-up due to the complexity of downstream separations, the development of economically viable processes for treating new LIB chemistries, the recovery of secondary components (electrolyte, anode, case materials), and the processing of secondary streams [1-3].

In recent years, much research has been undertaken to develop efficient pre-treatments of LIB batteries. Pre-treatments may include different combinations of physical and chemical operations, such as discharging of spent batteries in salt-saturated solutions [4], physical treatments (including heat treatments, crushing, shredding, milling) and separations (e.g. eddy currents, classification, gravimetric separation) [5-7]. These operations, which are typical of ore beneficiation, were 
tailored for battery treatment. Furthermore, cryo-millling and crushing in inert atmosphere were specifically developed for minimizing exothermic reactions, short circuits, and explosions occurring in battery treatment [8]. Ultrasound-assisted separation has also been successfully implemented to detach active materials from $\mathrm{Al}$ and $\mathrm{Cu}$ layers [2]. In addition, advanced operations, such as supercritical $\mathrm{CO}_{2}$ extraction, were integrated in pre-treatment section for electrolyte recovery [9].

Therefore, pre-treatment operations as a combination of traditional and innovative technologies allow separation and recovery of different valuable fractions from LIB: stainless steel, aluminum, copper and plastics, and black mass, the finest fraction containing the electrode materials [10]. The heterogeneity of chemistry used in $\mathrm{LIB}$, such as $\mathrm{LiCoO}_{2}, \mathrm{Li} \mathrm{Ni} \mathrm{Ni}_{33} \mathrm{Mn}_{0.33} \mathrm{Co}_{0.33} \mathrm{O}_{2}$ (NMC), $\mathrm{LiMn}_{2} \mathrm{O}_{4}$, $\mathrm{LiNi}_{0.8} \mathrm{Co}_{0.15} \mathrm{Al}_{0.05} \mathrm{O}_{2}$ (NCA) and $\mathrm{LiFePO}_{4}$ [11], led to a progressive variation of the composition of black mass collected on large-scale pre-treatment plants, with growing concentrations of new cathodic metals (e.g. Mn, Ni).

Despite many efforts have been done to increase the selectivity of leaching operations, aiming to the recovery of $\mathrm{Co}$ and transition metals (e.g. ammonia leaching for $\mathrm{Co}, \mathrm{Ni}, \mathrm{Cu}$ [12]), multiple selective leaching and/or downstream separations $[13,14]$ are needed in order to have satisfactory recovery rates and purity of the final products.

A promising approach was recently applied for synthesizing Li-mixed oxide $[15,16]$ instead of pure $\mathrm{LiCoO}_{2}$ [17] for producing new cathodic materials, taking into account both the heterogeneity of cathodic materials in LIB (often not suitable for producing pure $\mathrm{LiCoO}_{2}$ ) and the virtuous idea of re-synthesize new battery products from waste material (circular economy).

The present work copes with some of the present challenges in the field of LIB hydrometallurgical recycling, toward the development of a zero-waste process for treating the black mass. To such aim a black mass sample from real LIB waste collection, containing heterogeneous LIB chemistries, was obtained by a pilot scale pre-treatment plant. An optimized hydrometallurgical route was implemented to obtain commercial products. In addition, products that are not reaching market grade purity (Co and $\mathrm{Ni}$ oxides) were tested as conversion anodes in advanced LIB according to the pioneering work of Tarascon and co-workers [18] and many other following [1921].

The novelty aspects of the work are then different: (1) Use of pilot scale pre-treated black mass from large-scale collection of real LIB waste. (2) Recycling of both cathodic and anodic materials. (3) Minimization of wastes by reuse of metal-bearing streams for secondary productions. (4) Testing of recycled metal oxides in advanced LIB as conversion anodes, using ball-milling preparation of active material [22].

\section{Experimental}

\subsection{Materials}

For the hydrometallurgical operations the following reagent grade chemicals were used: $\mathrm{H}_{2} \mathrm{SO}_{4}$ (Sigma-Aldrich, 95.0\%-97.0\%), $\quad \mathrm{H}_{2} \mathrm{O}_{2}$ (Sigma-Aldrich, 34.5\%-36.5\%), D2EHPA- Bis(2ethylhexyl)phosphoric acid (Sigma-Aldrich, 97\%), Cyanex272® -Bis 2,4,4-trimethylpentyl phosphinic acid (kindly provided by Cytec, Engineered Materials Inc.), kerosene (Sigma-Aldrich), $\mathrm{Na}_{2} \mathrm{C}_{2} \mathrm{O}_{4}$ (Analyticals, Carlo Erba, 99.5\%), $\mathrm{NaOH}$ (Sigma-Aldrich, $\geq 98 \%$ ), $\mathrm{Na}_{2} \mathrm{CO}_{3}$ (Riedel-de Haën, 99.8\%), DTAB- Dodecyl trimethyl ammonium bromide (Acros Organics, 99\%), hexane (Sigma-Aldrich $>95 \%$ ).

For the preparation of conversion Li-ion batteries the following battery grade chemicals were used: NCA ( $\mathrm{LiNi}{ }_{0.8} \mathrm{Co}_{0.15} \mathrm{Al}_{0.05} \mathrm{O}_{2}$ ) by TODA America Inc., carbon black Super P®, graphite 
(Targray PG PT 202), polyvinylidene fluoride PVDF, N-Methyl-2-pyrrolidone (NMP), dimethyl carbonate (DMC), ethylene carbonate (EC), lithium hexafluorophosphate ( $\mathrm{LiPF}_{6}$, commercial name LP30, provided by UBE), fluoroethylene carbonate (FEC), lithium bis-oxalate-borate (LiBOB) and vinylene carbonate (VC).

A sample $(50 \mathrm{~kg}$ ) of LIBs collected by S.E.Val LTD. (Colico - LC, Italy) was processed by an automated pre-treatment pilot plant equipped with gas treatment section (gas scrubber and carbon filters) and made up of a series of operations including crushing, sieving, magnetic separation, and eddy currents. This automated pre-treatment enabled the recovery of scraps of copper (10 wt $\%$ of input material), scraps of aluminium (10\%), scraps of steel (12\%), a mixture of paper and plastics (18\%), and the black mass (50\%) [23] used as feed for the leaching process.

\subsection{Methods}

\subsubsection{Process scheme}

The block diagram of the hydrometallurgical section is reported in Fig. 1.

Electrodic powder was fed to the leaching section allowing quantitative metal extraction; leaching residue was further treated for pure graphite recovery, while leach liquor was purified by precipitation (giving a metal-bearing sludge) and three steps of solvent extraction allowing the removal of $\mathrm{Mn}$ and then the separation of Co from Ni. Co was recovered as hydroxide or oxalate, $\mathrm{Ni}$ as hydroxide and $\mathrm{Li}$ as carbonate after Na2SO 4 crystallization. Details about the operating conditions for all hydrometallurgical operations are reported in Supplementary Material.

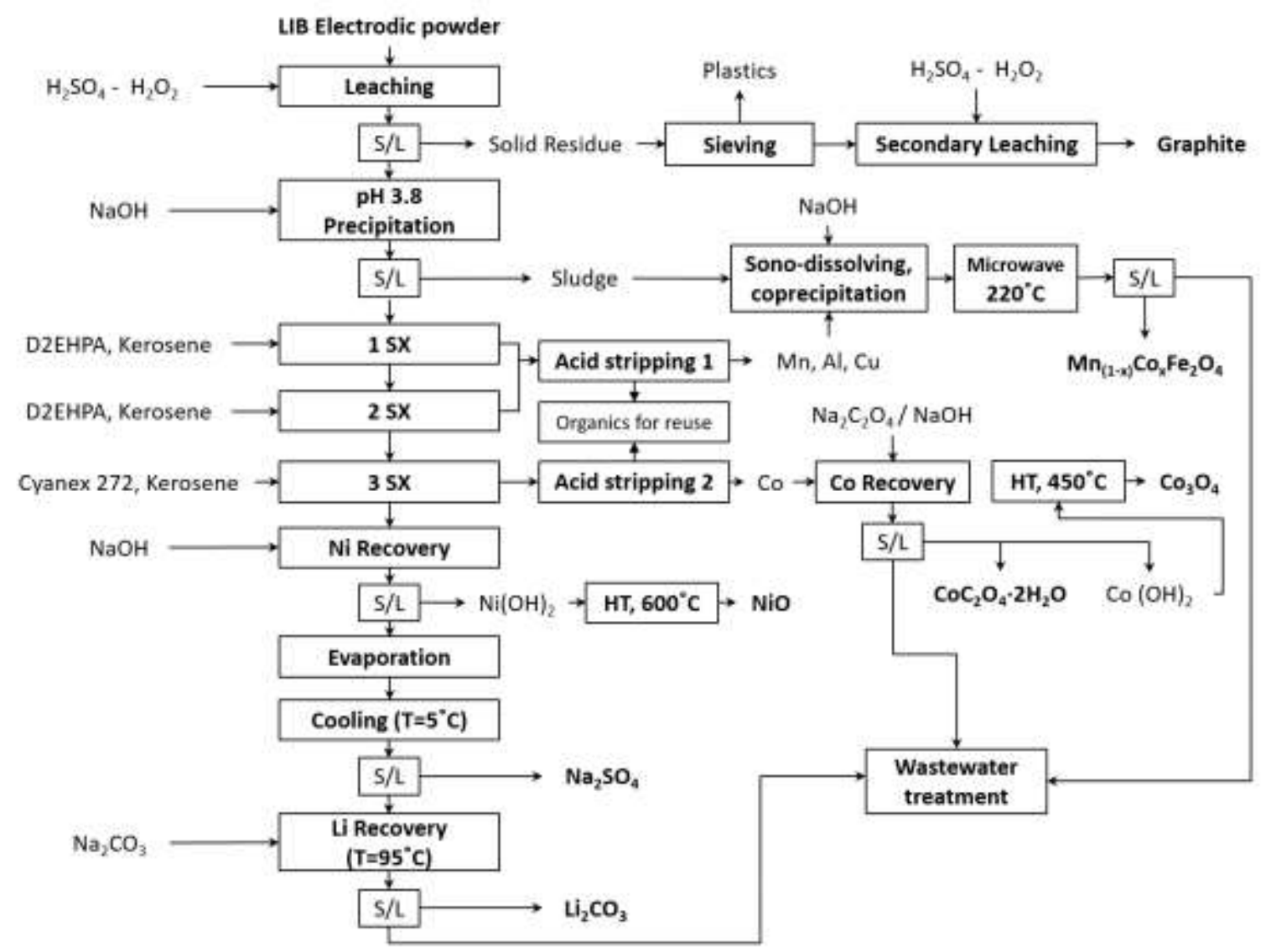

Fig. 1. LIB recycling hydrometallurgical section flowsheet, integrated with magnetic nano-powder production. S/L stands for solid-liquid separation, HT for heat treatments and organic for reuse is a chemical operation dedicated to organic phase regeneration with sodium hydroxide. 


\subsection{2 $\mathrm{Mn}-\mathrm{CoFe}_{2} \mathrm{O}_{4}$ synthesis}

Mn-Co ferrite nano-powder was obtained using the iron sludge resulting from purification of leach liquor by precipitation, and the Mn-bearing solution from the stripping of D2EHPA. $0.3 \mathrm{~g}$ of iron sludge were dissolved in $10 \mathrm{~mL}$ of stripping solution in presence of $0.1 \mathrm{~g}$ of DTAB. $\mathrm{pH}$ was gradually increased by $\mathrm{NaOH}\left(5 \mathrm{~mol} \mathrm{~L}^{-1}\right)$ up to 12.5 [30]. After $1 \mathrm{~h}$ mixing and 5-minute sonication, the mixture was quantitatively poured into Teflon-lined microwave vessels. Microwave treatment was performed in ETHOS Milestone 900 at $500 \mathrm{~W}$ for $2 \mathrm{~h}$ at $220{ }^{\circ} \mathrm{C}$. Mn-Co nanopowder was washed 3 times with $25 \mathrm{~mL}$ distilled water $(5 \mathrm{~min}, 3000 \mathrm{rpm})$. For the fourth, $10 \mathrm{~mL}$ of hexane substituted water to enhance product recovery by centrifugation/decantation. The nanopowder was dried at $105^{\circ} \mathrm{C}$ for $12 \mathrm{~h}$.

\subsubsection{Characterization of the products}

Metal content in all the products was determined by acid digestion at high-temperature in microwave Milestone ETHOS 900 followed by leachate analysis with high-resolution continuumsource atomic absorption spectroscopy HR-CS AAS (ContrAA 300 Analitikjena). AAS analysis was also used to determine cobalt, lithium, aluminium, copper, iron, nickel, manganese, and sodium in all liquid streams.

Solid products were analyzed using SEM equipped with EDX (FE-SEM Zeiss Auriga and SUPRA 55VP) and X-ray diffraction (Rigaku Ultima+, $\mathrm{Cu} \mathrm{K \alpha}=0.15418 \mathrm{~nm}$ ).

\subsubsection{Re-use of metal oxides as conversion-type anode materials for advanced LIB}

Recovered cobalt and nickel oxides $\left(\mathrm{Co}_{3} \mathrm{O}_{4}\right.$ and $\left.\mathrm{NiO}\right)$ were used as active materials for thin film anodes preparation. Both oxides were firstly dried in vacuum $\left(T=80{ }^{\circ} \mathrm{C}, P=10^{-3}\right.$ bar, overnight) and then mixed with graphite (PG PT 202) under argon atmosphere using $60 \mathrm{wt} \%$ of recycled oxides and $40 \mathrm{wt} \%$. of graphite [21,22,31]. The solid mixture was mechanically treated in high energy ball-mill (Retsch E-Max) using a ratio powder to balls equal to 1:10, alternating $15 \mathrm{~min}$ of milling (1500 rpm) and $45 \mathrm{~min}$ of rest (a total of $48 \mathrm{~h}$ ) [21,22,31].

Slurry of milled active materials $\left(\mathrm{Co}_{3} \mathrm{O}_{4}\right.$ and $\mathrm{NiO}$, plus graphite), super $\mathrm{P}$, and PVDF was suspended in NMP with the weight ratio 80:10:10 respectively and deposited onto copper foils by doctor blade technique. The coated copper foils were dried at $60{ }^{\circ} \mathrm{C}$ and cut into $10 \mathrm{~mm}$ disks suitable for Swagelock T-cells. The electrode disks were dried under vacuum at $110{ }^{\circ} \mathrm{C}$ overnight to remove solvent residues.

The same procedure was employed to prepare the $\mathrm{NCA}\left(\mathrm{LiNi}_{0.8} \mathrm{Co}_{0.15} \mathrm{Al}_{0.05} \mathrm{O}_{2}\right.$, kindly provided by TODA America, Inc) cathodic material onto aluminium foil. As electrolyte, a mixture of DMC and EC (volumetric ratio $1: 1$ ) and $1 \mathrm{~mol} \mathrm{~L}^{-1} \mathrm{LiPF}_{6}$ was used. Additionally, different additive solutions (+ $2 \mathrm{wt} \%$ ) were added to the electrolyte: FEC, LiBOB, and VC.

The electrochemical tests were performed in Swagelock T cells, where lithium metal operated both as reference and counter electrode. The electrolyte-soaked Whatman disk was used as separator. Full-cells (NCA-recycled) were assembled inside a glove box in argon atmosphere $\left(\mathrm{O}_{2}\right.$ and $\mathrm{H}_{2} \mathrm{O}<0.1 \mathrm{ppm}$ ) and electrochemically tested using a MACCOR 4000 SYSTEM.

\section{Results and discussion}

\subsection{Leaching of the black mass}

The electrode-rich powder obtained by physical pre-treatment (black mass) is composed of carbon, cobalt, manganese, nickel, lithium, aluminum, copper, iron, phosphorous, and fluorine, evidencing a heterogeneous composition of starting LIB waste (see EDX reported in Fig. S1 of Supplementary Material). Metal content determined by acid digestion is reported in Table 1. 
Table 1. Metal concentrations of main solids involved within the LIB recycling process ${ }^{\mathrm{a}}$.

\begin{tabular}{lllllllll}
\hline Metals & $\begin{array}{l}\mathrm{Co} \\
(\mathrm{mg} / \mathrm{g})\end{array}$ & $\begin{array}{l}\mathrm{Li} \\
(\mathrm{mg} / \mathrm{g})\end{array}$ & $\begin{array}{l}\mathrm{Cu} \\
(\mathrm{mg} / \mathrm{g})\end{array}$ & $\begin{array}{l}\mathrm{Ni} \\
(\mathrm{mg} / \mathrm{g})\end{array}$ & $\begin{array}{l}\mathrm{Mn} \\
(\mathrm{mg} / \mathrm{g})\end{array}$ & $\begin{array}{l}\mathrm{Fe} \\
(\mathrm{mg} / \mathrm{g})\end{array}$ & $\begin{array}{l}\mathrm{Al} \\
(\mathrm{mg} / \mathrm{g})\end{array}$ & $\begin{array}{l}\mathrm{Na} \\
(\mathrm{mg} / \mathrm{g})\end{array}$ \\
\hline LIB powder & $227 \pm 5$ & $37 \pm 3$ & $13 \pm 1$ & $55 \pm 2$ & $58 \pm 3$ & $20 \pm 1$ & $10 \pm 2$ & $<\mathrm{LOD}$ \\
$\mathrm{Co}_{3} \mathrm{O}_{4}$ & $601 \pm 5$ & $<\mathrm{LOD}$ & $1.1 \pm 0.5$ & $12 \pm 1$ & $22 \pm 3$ & $<\mathrm{LOD}$ & $2.5 \pm 0.3$ & $5.3 \pm 0.8$ \\
$\mathrm{CoC}_{2} \mathrm{O}_{4}$ & $306 \pm 4$ & $<\mathrm{LOD}$ & $<\mathrm{LOD}$ & $<\mathrm{LOD}$ & $<\mathrm{LOD}$ & $<\mathrm{LOD}$ & $<\mathrm{LOD}$ & $<\mathrm{LOD}$ \\
$\mathrm{NiO}$ & $8 \pm 1$ & $0.5 \pm 0.2$ & $<\mathrm{LOD}$ & $795 \pm 10$ & $<\mathrm{LOD}$ & $<\mathrm{LOD}$ & $<\mathrm{LOD}$ & $2.2 \pm 0.5$ \\
$\mathrm{Na}_{2} \mathrm{SO}_{4}$ & $<\mathrm{LOD}$ & $6.6 \pm 0.1$ & $<\mathrm{LOD}$ & $<\mathrm{LOD}$ & $<\mathrm{LOD}$ & $<\mathrm{LOD}$ & $<\mathrm{LOD}$ & $305 \pm 6$ \\
$\mathrm{Li}_{2} \mathrm{CO}_{3}$ & $<\mathrm{LOD}$ & $188 \pm 1$ & $<\mathrm{LOD}$ & $<\mathrm{LOD}$ & $<\mathrm{LOD}$ & $<\mathrm{LOD}$ & $<\mathrm{LOD}$ & $0.6 \pm 0.9$ \\
$\mathrm{Mn}-\mathrm{CoFe}_{2} \mathrm{O}_{4}$ & $95 \pm 8$ & $<\mathrm{LOD}$ & $<\mathrm{LOD}$ & $<\mathrm{LOD}$ & $150 \pm 20$ & $460 \pm 10$ & $<\mathrm{LOD}$ & $<\mathrm{LOD}$ \\
\hline
\end{tabular}

${ }^{\mathrm{a}}$ Metal concentrations were assayed by microwave digestion of the solids at $220{ }^{\circ} \mathrm{C}$ in aqua regia (and $\mathrm{H}_{2} \mathrm{O}_{2}$, if needed) followed by HR-CS AAS analysis.

The black mass was leached with hydrogen peroxide-sulfuric acid mixture, achieving high yields of metal extraction (Table 2): average values of $99 \%$ for lithium and copper, $98 \%$ for cobalt and nickel, $96 \%$ for manganese, $95 \%$ and $94 \%$ for iron and aluminium. Besides the effectiveness of extraction, the use of sulphuric acid has another advantage with respect to alternative organic acids [32-34] such as the absence of residual organics into the leach liquor [35], potentially hampering downstream purification-separation stages, and purity of products, accordingly. Finally, using sulphuric acid, sulfates can be recovered at the end of the process as salts.

Table 2. Efficiencies (expressed in percentage units, \%) of the single chemical operation composing the hydrometallurgical LIB recycling ${ }^{\mathrm{a}}$.

\begin{tabular}{lllllllll}
\hline Operation & Yield (\%) & $\mathrm{Co}$ & $\mathrm{Li}$ & $\mathrm{Fe}$ & $\mathrm{Cu}$ & $\mathrm{Ni}$ & $\mathrm{Mn}$ & $\mathrm{Al}$ \\
\hline Leaching & Of extraction & $98 \pm 2$ & $99 \pm 1$ & $95 \pm 3$ & $99 \pm 1$ & $97 \pm 2$ & $96 \pm 2$ & $94 \pm 5$ \\
$\begin{array}{l}\text { First } \\
\text { purification }\end{array}$ & Of precipitation & $0.2 \pm 0.1$ & $4 \pm 1$ & 100 & $12 \pm 1$ & $2 \pm 1$ & $16 \pm 3$ & $6 \pm 2$ \\
D2EHPA SX & $\begin{array}{l}\text { Of extraction } \\
\text { organic phase }\end{array}$ & $5 \pm 2$ & $3 \pm 1$ & $/$ & $77 \pm 4$ & $3 \pm 1$ & $80 \pm 5$ & $93 \pm 3$ \\
Cyanex SX & $\begin{array}{l}\text { Of extraction in } \\
\text { organic phase }\end{array}$ & 100 & $3 \pm 2$ & $/$ & 100 & $4 \pm 2$ & 100 & 100 \\
\hline
\end{tabular}

${ }^{a}$ Metals extraction of leaching, metals precipitation for the first purification and metals extraction in organic phase for D2HEPA and Cyanex 272 liquid-liquid separations (the stripping was quantitative in the operative conditions, not reported) considering the main metals found in the LIB powder (Co, $\mathrm{Li}, \mathrm{Cu}, \mathrm{Ni}, \mathrm{Mn}, \mathrm{Fe}, \mathrm{Al}, \mathrm{Na})$.

$\mathrm{H}_{2} \mathrm{O}_{2}$ is used as reducing agent for the reduction of oxidized cobalt in the black mass to soluble $\mathrm{Co}^{2+}$ species. Additionally, a partial oxidation of graphite was promoted, favoring the deintercalation of metals, and enhancing the final purity of graphite. The leach residue was sieved for cutting off plastic and steel residues, corresponding to $8 \mathrm{wt} \%$ of residue weight. The sieved material evidenced a typical platelet-like structure (Fig. S2a) [36,37]. However, EDX microanalysis (Fig. S3a) showed the presence of carbon (74\%) and oxygen (6\%), but also fluorine (19\%) and cobalt (1\%) from electrolyte and cathode material, respectively. In addition, the electronic-grade silicon specimen gave a minor Si contribution $(0.26 \%)$. 
After the second leaching, fluorine and metals were completely removed: only carbon $(95.87 \%)$, oxygen $(2.65 \%)$ and sulfur $(0.48 \%)$ remained (Fig. S3b), denoting high-grade graphite. The final graphite product consisted of layered polygonal structures (Fig. S2b). This might indicate a slight exfoliation of the carbon sheets [38] due to this second leaching stage, probably for interlayer oxidation/sulfating mechanisms, according to the observation of local bulges on the external graphite layers. The XRD pattern (Fig. 2, pattern A) revealed a crystalline habit of hard carbon (hexagonal, $2 \mathrm{H}$ ), confirming that the structure was maintained.
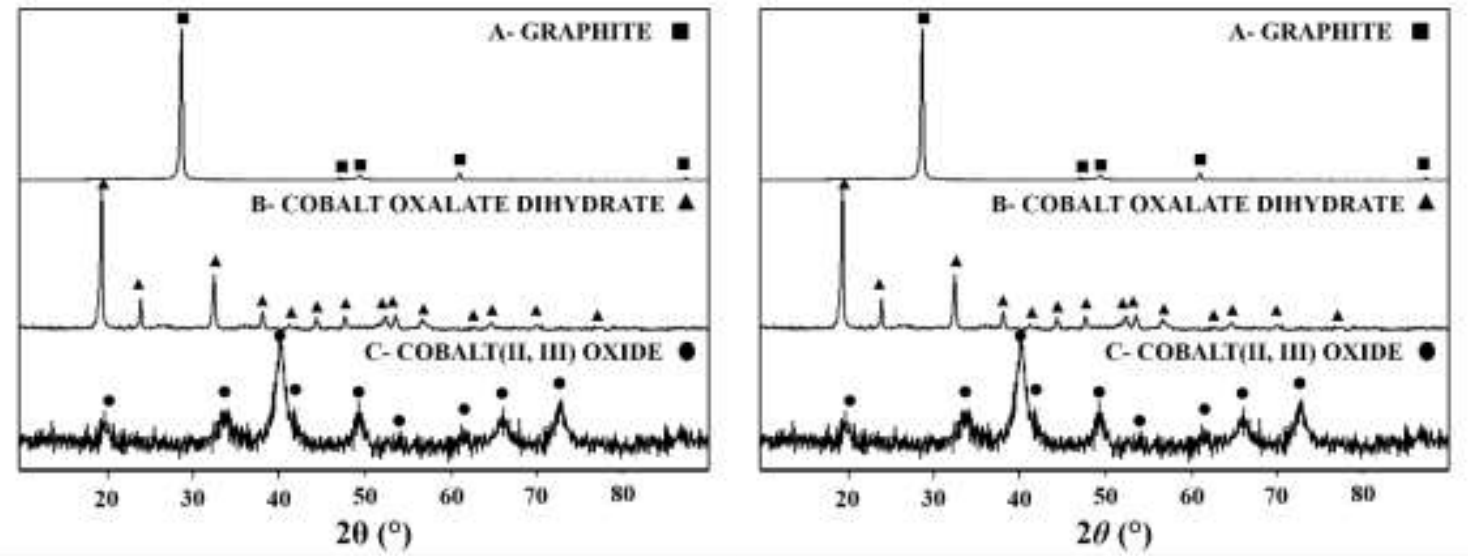

Fig. 2. XRD patterns of graphite (pattern $A$ ), $\mathrm{Co}_{3} \mathrm{O}_{4}$ (pattern $\mathrm{B}$ ) and $\mathrm{CoC}_{2} \mathrm{O}_{4} \cdot 2 \mathrm{H}_{2} \mathrm{O}$ (pattern $\mathrm{C}$ ).

Furthermore, no metal contamination was detected, showing at least comparable purity as the graphite product obtained from individual LIB anode material by $\mathrm{HCl}$ leaching [39]. Although minor Li (-organic) phases cannot be completely excluded [39], the microwave assisted digestion of the final graphite gave concentrations in solution below detection limit for all metals $(\mathrm{Co}, \mathrm{Li}, \mathrm{Na}$, $\mathrm{Al}, \mathrm{Fe}, \mathrm{Cu}, \mathrm{Ni}, \mathrm{Mn}$ ).

Previous works evidenced satisfactory electrochemical properties of recycled graphite from pre-lithiated materials [40], although still not comparable with virgin graphite ( $\geq 99.9 \%)$. It should be noted that surface modifications may enhance the features of this recycled material [41].

The graphite fraction was $32 \mathrm{wt} \%-34 \mathrm{wt} \%$ of the black mass and 15-16 wt $\%$ of the whole LIB waste, accordingly.

\subsection{Purification of leachate}

Leach liquor purification was performed by precipitation and solvent extraction. The efficiencies for metal precipitation and separation by solvent extraction are resumed in Table 2 and the composition of the liquid streams is presented in Table 3.

Table 3. HR-CS AAS analysis of metals contained in the liquid streams after hydrometallurgical separations, before and after products recovery.

\begin{tabular}{llllllll}
\hline Metals $(\mathrm{mg} / \mathrm{L})$ & $\mathrm{Co}$ & $\mathrm{Li}$ & $\mathrm{Cu}$ & $\mathrm{Ni}$ & $\mathrm{Mn}$ & $\mathrm{Al}$ & $\mathrm{Na}$ \\
\hline $\begin{array}{l}\text { Cobalt recovery } \\
\text { solution }\end{array}$ & $16650 \pm 90$ & $121 \pm 7$ & $250 \pm 5$ & $158 \pm 4$ & $800 \pm 80$ & $98 \pm 4$ & $8600 \pm 100$ \\
$\begin{array}{l}\text { Post } \mathrm{Co}_{3} \mathrm{O}_{4} \\
\text { solution }\end{array}$ & $<\mathrm{LOD}$ & $107 \pm 6$ & $<\mathrm{LOD}$ & $<\mathrm{LOD}$ & $<\mathrm{LOD}$ & $<\mathrm{LOD}$ & $27000 \pm 300$ \\
$\begin{array}{l}\text { Post } \mathrm{CoC}_{2} \mathrm{O}_{4} \\
\text { solution }\end{array}$ & $780 \pm 20$ & $120 \pm 4$ & $243 \pm 7$ & $146 \pm 6$ & $770 \pm 40$ & $100 \pm 10$ & $24000 \pm 150$ \\
$\begin{array}{l}\text { Nickel recovery } \\
\text { solution }\end{array}$ & $100 \pm 8$ & $2900 \pm 40$ & $<$ LOD & $3760 \pm 40$ & $<$ LOD & $<$ LOD & $21500 \pm 200$ \\
\hline
\end{tabular}




\begin{tabular}{llclllll}
\hline $\begin{array}{l}\text { Post } \mathrm{NiO} \\
\text { solution }\end{array}$ & $<$ LOD & $2890 \pm 20$ & $<$ LOD & $<$ LOD & $<$ LOD & $<$ LOD & $30700 \pm 400$ \\
$\begin{array}{l}\text { Post } \\
\text { evaporation- }\end{array}$ & $<$ LOD & $14100 \pm 200$ & $<$ LOD & $<$ LOD & $<$ LOD & $<$ LOD & $27500 \pm 200$ \\
$\mathrm{Na}_{2} \mathrm{SO}_{4}$ & & & & & & & \\
$\begin{array}{l}\text { Post } \mathrm{Li}_{2} \mathrm{CO}_{3} \\
\text { solution }\end{array}$ & $<$ LOD & $1070 \pm 20$ & $<$ LOD & $<$ LOD & $<$ LOD & $<$ LOD & $16800 \pm 250$ \\
\hline
\end{tabular}

The first purification of leach liquor removed iron quantitatively, while only partial removal of manganese, copper, and aluminum $(16 \%, 12 \%$ and $6 \%$, respectively) was achieved to minimize losses of cobalt, nickel, and lithium $(0.2 \%, 2 \%$ and $4 \%$, respectively). The two-stage extraction with D2EHPA removed up to $93 \%$ of aluminum, $80 \%$ of manganese and $77 \%$ of copper. Cyanex is highly selective for $\mathrm{Co}-\mathrm{Ni}$ separation leaving $\mathrm{Ni}$ in aqueous phase, but if also $\mathrm{Al}, \mathrm{Mn}$, and $\mathrm{Cu}$ are present, these metals are also co-extracted in the organic phase. For this reason, D2EHPA extraction was introduced before Cyanex, to preliminarily remove such metals.

Leaching and purification conditions here reported have been optimized according to the black mass composition. Nevertheless, the solvent extraction section makes the process route flexible with respect to changes of the chemical compositions of the black powder. Different LIB cathodes, such as layered oxides $\left(\mathrm{LiCoO}_{2}, \mathrm{LiNiO}_{2}\right)$, lithium-mixed transition metals oxide $\left(\mathrm{LiNiCoAlO}_{2}\right.$, LiNiMnCoO 2$)$ and spinels $\left(\mathrm{LiMn}_{2} \mathrm{O}_{4}\right)$ [42] can be treated according to the same route.

\subsection{Cobalt recovery}

Cobalt was recovered from stripping solution of Cyanex extraction as oxide or oxalate. For the cobalt oxide production cobalt was precipitated as hydroxide and then thermally treated to obtain the oxide. Two polymorphic forms of cobalt hydroxide exist, $\alpha-\mathrm{Co}(\mathrm{OH})_{2}$ and $\beta-\mathrm{Co}(\mathrm{OH})_{2}$, which mainly differ in spacing between hydroxide layers [43]. When directly precipitated with hydroxide, cobalt tends to form $\alpha-\mathrm{Co}(\mathrm{OH})_{2}$, which is made up of $\beta-\mathrm{Co}(\mathrm{OH})_{2}$ sheets intercalated with water molecules [44]. $\mathrm{pH}$ of precipitation was set on the base of earlier experimental findings denoting quantitative precipitation of $\mathrm{Co}$ at $\mathrm{pH}=11$ (experimental results not reported here).

Cobalt hydroxide starts converting to $\mathrm{Co}_{3} \mathrm{O}_{4}$ at $300{ }^{\circ} \mathrm{C}$, but the complete conversion is reached at $450-500{ }^{\circ} \mathrm{C}$ [27]. Cobalt oxide (Fig. S2c) obtained at $450{ }^{\circ} \mathrm{C}$ was mainly composed of cobalt (60 $\mathrm{wt} \%)$, nickel (1.2 wt \%), manganese (2.2 wt $\%)$, copper $(0.1 \mathrm{wt} \%)$ and aluminium $(0.5 \mathrm{wt} \%)$ according to the metal content determined by acid digestion (Table 1) and elemental analysis by EDX (Fig. S3c). Despite D2EHPA and Cyanex 272 treatments, co-extracted Al, Cu and Mn precipitated as hydroxides during Co recovery and therefore converted to oxides during final thermal treatment. As such, the hydroxide route is not highly selective, since in presence of other divalent cations and anions, the hydroxide crystallizes as $\mathrm{M}_{(1-y)}^{\mathrm{a}} \mathrm{M}_{y}^{\mathrm{b}}(\mathrm{OH})_{2-x}\left(\mathrm{~A}^{m-}\right)_{x / m} \cdot n \mathrm{H}_{2} \mathrm{O}$, where $\mathrm{M}^{\mathrm{a}}$ is cobalt, $\mathrm{M}^{\mathrm{b}}$ a different metal and $\mathrm{A}^{m^{-}}$is an interstitial anion [44].

About $4 \%$ of sulphur was also detected, indicating that some $\mathrm{SO}_{4}{ }^{2-}$ anions, from sulfuric acid stripping, were incorporated within the oxide sheets. The XRD pattern (Fig. 2, pattern B) showed the formation of a bulk-phase of cobalt oxide. By this route, $85 \%-86 \%$ of the cobalt of the LIB powder can be recovered as $\mathrm{Co}_{3} \mathrm{O}_{4}$ with a purity of $82 \%-83 \%$.

The oxalate route was more selective towards Co recovery giving high purity product. Co oxalate disclosed a highly ordered microstructure: cuboids and truncated octahedrons were observed by FE-SEM images (Fig. S2d). In this regard, the XRD pattern (Fig. 2, pattern C) perfectly matched peaks and intensities of $\mathrm{CoC}_{2} \mathrm{O}_{4} \cdot 2 \mathrm{H}_{2} \mathrm{O}[32,45]$. The final purity of the 
$\mathrm{CoC}_{2} \mathrm{O}_{4} \cdot 2 \mathrm{H}_{2} \mathrm{O}$ varied between $94 \%-96 \%$, according to chemical digestion results (Table 3) and EDX (Fig. S3d). Both these analytical characterizations showed that cobalt was the only metal in the solid.

Carbon and oxygen amounts well approximated the atomic ratio for cobalt oxalate. This is in agreement with metal solubility of $\mathrm{Mn}$ and $\mathrm{Li}$ as oxalate $\left(0.028\right.$ and $8 \mathrm{~g} / 100 \mathrm{~g} \mathrm{H}_{2} \mathrm{O}$, respectively), which are more soluble than $\left(\mathrm{Co} 2.69 \times 10^{-9} \mathrm{~g} / 100 \mathrm{~g} \mathrm{H}_{2} \mathrm{O}\right)$. On the contrary, the presence of copper and nickel oxalates should be expected considering only their solubility as oxalate $\left(2.16 \times 10^{-10}\right.$ and $3.98 \times 10^{-10} \mathrm{~g} / 100 \mathrm{~g} \mathrm{H}_{2} \mathrm{O}$ at $20{ }^{\circ} \mathrm{C}, 1 \mathrm{~atm}$, respectively). This result may be explained by the formation of charged soluble oxalates, $\mathrm{Cu}\left(\mathrm{C}_{2} \mathrm{O}_{4}\right)_{2}{ }^{2-}$ and $\mathrm{Ni}\left(\mathrm{C}_{2} \mathrm{O}_{4}\right)_{2}{ }^{2-}$, generated at high concentrations of oxalate. For the same reason, cobalt partially remained in solution through the formation of $\mathrm{Co}\left(\mathrm{C}_{2} \mathrm{O}_{4}\right)_{2}{ }^{2-}$, even upon further excess addition of $\mathrm{Na}_{2} \mathrm{C}_{2} \mathrm{O}_{4}$.

The concentration of cobalt in oxalate was about $30 \mathrm{wt} \%$, which lies within the range of commercial grade $\mathrm{CoC}_{2} \mathrm{O}_{4} \cdot 2 \mathrm{H}_{2} \mathrm{O}$ (26 wt $\%-32 \mathrm{wt} \%$ of cobalt). Nevertheless, the absolute cobalt recovery by this route was only $79 \%-80 \%$, then lower than that by $\mathrm{Co}_{3} \mathrm{O}_{4}$ route. Both cobalt products are fluorine and phosphorous free since during solvent extraction anionic species are not transferred to the organic phase. Although the purity of the recovered cobalt oxide does not achieve market grade, it can still be applied as mixed transition metal-oxide for cathodes in LIB (e.g. NCA, NCM). In this work, a breakthrough application was alternatively attempting to reuse these mixed oxides as conversion anodes for advanced LIB.

The advantage of cobalt (hydro-)oxide route is to recollect the cobalt-depleted solution, bearing $\mathrm{Na}$ (Table 3, post $\mathrm{Co}_{3} \mathrm{O}_{4}$ solution), which can be fed directly to Li-Na separation for recovering $\mathrm{Na}$ and water. On the other hand, in the case of oxalate recovery, metal-bearing solutions (Table 3, post $\mathrm{CoC}_{2} \mathrm{O}_{4}$ solution) need further processing or wastewater treatment for oxalate removal.

\subsection{Nickel recovery}

Nickel was obtained as hydroxide from the aqueous solution after Cyanex extraction. The precipitation $\mathrm{pH}$ was fixed to 11 to achieve quantitative recovery of nickel [46] and reduce lithium losses (in these conditions lithium hydroxide starts precipitating at $\mathrm{pH}$ higher than 12). The solution also contained $\mathrm{Na}^{+}$and $\mathrm{SO}_{4}{ }^{2-}$ ions, which partially co-precipitated as $\mathrm{Na}_{2} \mathrm{SO}_{4}$ together with nickel hydroxide $\left(\mathrm{Na}_{2} \mathrm{SO}_{4}\right.$ white precipitate was eliminated by washing).

Cobalt remained in solution after solvent extraction, was incorporated in Ni hydroxide phase by co-precipitation (Table 2) as $\mathrm{Ni}_{(1-y)} \mathrm{Co}_{y}(\mathrm{OH})_{2-x}\left(\mathrm{~A}^{m-}\right)_{x / m} \cdot n \mathrm{H}_{2} \mathrm{O}$. Furthermore, it is plausible to have $\mathrm{PO}_{4}{ }^{3-}, \mathrm{SO}_{4}{ }^{2-}$ and $\mathrm{F}^{-}$as interstitial anions $\left(\mathrm{A}^{m-}\right)$. When precipitated, nickel hydroxide had the characteristic green color. The XRD pattern of $\mathrm{Ni}(\mathrm{OH})_{2}$ (Fig. S4) showed similarities with those obtained by other authors, associated for instance to nickel hydroxide thin layer [47] or precursor [48]. Nickel is a raw material for battery production both as hydroxide (for obtaining $\mathrm{NiOOH}$ electrodes) [49] and oxide for LIB electrodes [50]. In this work, nickel hydroxide was thermally converted to $\mathrm{NiO}$ and used as conversion anodes in advanced LIB. The obtained NiO (Fig. S5a) was a non-stoichiometric black oxide, because the nickel to oxygen ratio was not exactly 1:1 [47]. Acid digestion results (Table 3 ) denoted that nickel oxide was formed by nickel ( $80 \mathrm{wt} \%)$, cobalt $(0.8$ wt $\%)$, sodium $(0.2 \mathrm{wt} \%)$, and lithium $(0.05 \mathrm{wt} \%)$. As already mentioned, EDX (Fig. S6a) showed traces of sulphur and phosphorous, most probably due to inter-layer anions from sulfuric acid and electrolyte. Detected carbon, about $1.7 \%$, can be ascribed to SEM carbon tape, but minor contributions of organic anions from electrolyte cannot be excluded. The co-precipitation of metals and anions affected the stoichiometry and generated flaws into $\mathrm{NiO}$ crystal lattice. X-ray diffraction 
proved the formation of a main phase of nickel oxide (Fig. 3, pattern A). By this route, a purity of $87 \%-89 \%$ of $\mathrm{NiO}$ was obtained with a recovery rate above $89 \%$ for $\mathrm{Ni}$.
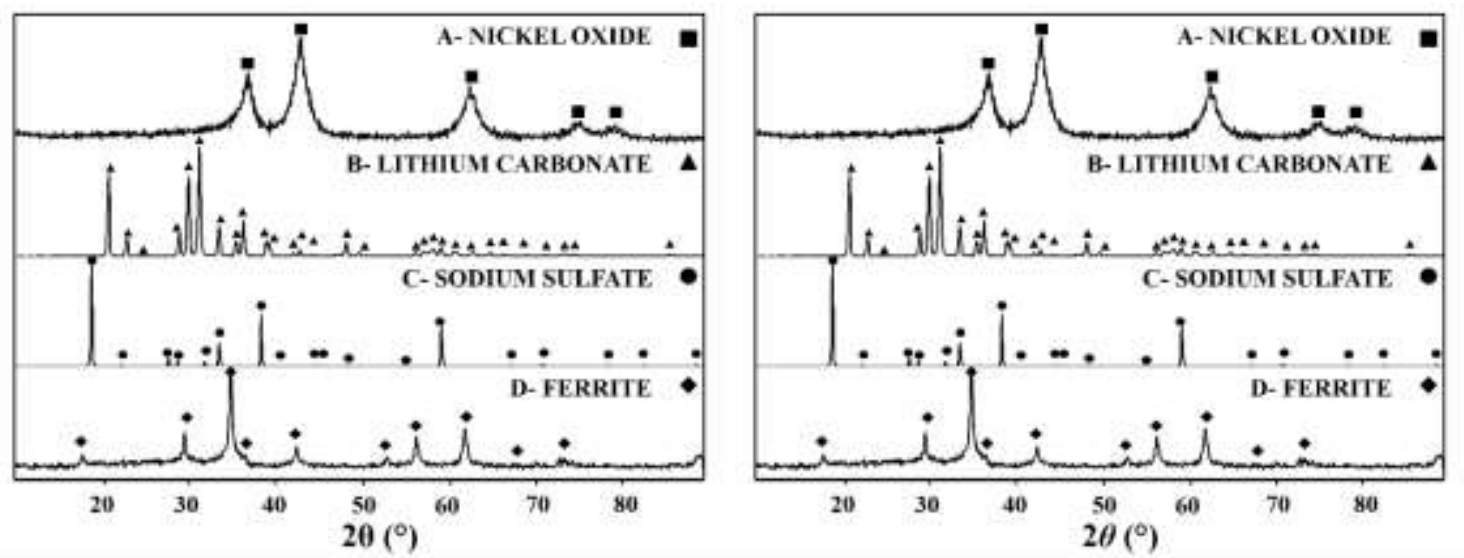

Fig. 3. XRD patterns of $\mathrm{NiO}$ (pattern A), $\mathrm{Li}_{2} \mathrm{CO}_{3}$ (pattern $\mathrm{B}$ ), $\mathrm{Na}_{2} \mathrm{SO}_{4}$ (pattern $\mathrm{C}$ ) and $\mathrm{Mn}_{(1-}$ ${ }_{x} \mathrm{Co}_{x} \mathrm{Fe}_{2} \mathrm{O}_{4}$ nano-powder (pattern D).

\subsection{Lithium-sodium separation and recovery}

The recovery of $\mathrm{Na}_{2} \mathrm{SO}_{4}$ before $\mathrm{Li}_{2} \mathrm{CO}_{3}$ precipitation is an innovative part of the hydrometallurgical route. The attempts to recover $\mathrm{Li}_{2} \mathrm{CO}_{3}$ by carbonatation at $95{ }^{\circ} \mathrm{C}$ using $\mathrm{Li}$ bearing dilute solution led to a product containing $\mathrm{Na}_{2} \mathrm{SO}_{4}$ and $\mathrm{Na}_{2} \mathrm{CO}_{3}$ with unsatisfactory $\mathrm{Li}$ recovery. The pre-separation of $\mathrm{Na}$ by direct cooling to $5{ }^{\circ} \mathrm{C}$ of the Li-bearing dilute solution led to poor recovery of $\mathrm{Na}_{2} \mathrm{SO}_{4}$, hindering the obtainment of pure lithium carbonate due to successive $\mathrm{Na}_{2} \mathrm{SO}_{4}$ coprecipitation upon heating and $\mathrm{Na}_{2} \mathrm{CO}_{3}$ addition. Best results were obtained by evaporation of the Li-bearing solution, removal of $\mathrm{Na}_{2} \mathrm{SO}_{4}$ by crystallization after cooling, and then precipitation of $\mathrm{Li}_{2} \mathrm{CO}_{3}$ by adding $\mathrm{Na}_{2} \mathrm{CO}_{3}$.

In this way, a pure phase of zabuyelite $\left(\mathrm{Li}_{2} \mathrm{CO}_{3}\right) 99.6 \%-99.8 \%$ pure was obtained as confirmed by XRD (Fig 3, pattern B), acid digestion (Table 1) and EDX (Fig. S6b). SEM images (Fig. S5b) revealed the characteristic microstructures of zabuyelite [51]. Only $0.06 \%$ of sodium was observed as impurity. By this route, the maximum recovery rate of lithium was about $70 \%-72 \%$. Regarding $\mathrm{Na}_{2} \mathrm{SO}_{4}$, macroscopic rhombohedral structures [52,53] were obtained (Fig. S5c). XRD pattern of $\mathrm{Na}_{2} \mathrm{SO}_{4}$ (Fig. 3, pattern C) showed a single phase of thenardite, having a purity of $96 \%$. This agreed with EDX (Fig. S6c) and acid digestion data, which only detected $\approx 0.7 \%$ of lithium inside $\mathrm{Na}_{2} \mathrm{SO}_{4}$. More than $90 \%$ of sodium and $75 \%$ of sulfate anions used along the entire process, were recovered in this additional product.

$\mathrm{Na}_{2} \mathrm{SO}_{4}$ is widely applied in detergent manufactory, textile industry and desiccating application [54]. Alternatively, $\mathrm{Na}_{2} \mathrm{SO}_{4}$ could be profitably converted to $\mathrm{NaOH}$ and $\mathrm{H}_{2} \mathrm{SO}_{4}$ by bipolar membrane electrodialysis $[55,56]$ supplying the base reagents for the hydrometallurgical recycling. The route including evaporation is energy intensive but makes use of conventional technologies already applied in lithium production and refining. In addition, the entire process can benefit from evaporation in terms of water balance and wastewater treatment. Finally, heat exchangers may also be used to recover heat, which might be supplied to the leaching operation.

\subsection{Nano-ferrite production}

Iron sludge from the first purification step (precipitation at $\mathrm{pH}=3.8$ ) and $\mathrm{Mn}$-bearing solution from D2EHPA extraction and stripping were used as starting materials for nano-ferrite production 
by microwave assisted hydrothermal treatment [57]. A well-organized cubic-shaped network of nano-structures (Fig. S5d) was repeated over all solid surface extension at microscale [58]. The size of these cubic structures varied between 20 and $60 \mathrm{~nm}$ according to FE-SEM profile width measuring system.

The XRD pattern of the obtained magnetic powder (Fig. 3, pattern D) was associated to mixed Mn-Co ferrite: $\mathrm{Mn}_{(1-x)} \mathrm{Co}_{x} \mathrm{Fe}_{2} \mathrm{O}_{4}$ [59,60] whereby $\mathrm{Mn}$ and Co substitute iron in octahedral and tetrahedral sublattices. The EDX elemental composition (Fig. S6d) and acid digestion analyses (Table 1) showed that Fe, Mn and Co were present as metals. This nano-powder can be used for metal adsorption in solution, exploiting the high specific area and the magnetic features [61] but as well as conversion anode materials in advanced LIB [62].

\subsection{Recycled $\mathrm{Co}_{3} \mathrm{O}_{4}$ and $\mathrm{NiO}$ as conversion anodes for advanced $\mathrm{LIB}$}

SEM images of anode materials $\left(\mathrm{Co}_{3} \mathrm{O}_{4}\right.$ in Fig. S7a, c, d and $\mathrm{NiO}$ in Fig. S7b) evidenced that metal oxides are present as particles with size smaller than $1 \mu \mathrm{m}$ embedded in the amorphous carbon matrix as typically occurs in ball milling preparation [21,22,31]. This morphology is expected to positively influence the electrochemical properties of the material in lithium batteries [21,22,31].

Fig. 4 reports the electrochemical behavior of the two-investigated anode materials in lithium cells. Fig. 4(a) shows the comparison of first cycle voltage profile of $\mathrm{Co}_{3} \mathrm{O}_{4}$ (straight line) and $\mathrm{NiO}$ (dotted line). $\mathrm{Co}_{3} \mathrm{O}_{4}$ showed a first plateau at about $1 \mathrm{~V}$, associated to the conversion reaction of $\mathrm{Co}_{3} \mathrm{O}_{4}$ with the formation of $\mathrm{LiO}_{2}$ and metal $\mathrm{Co}$ (reaction 11).
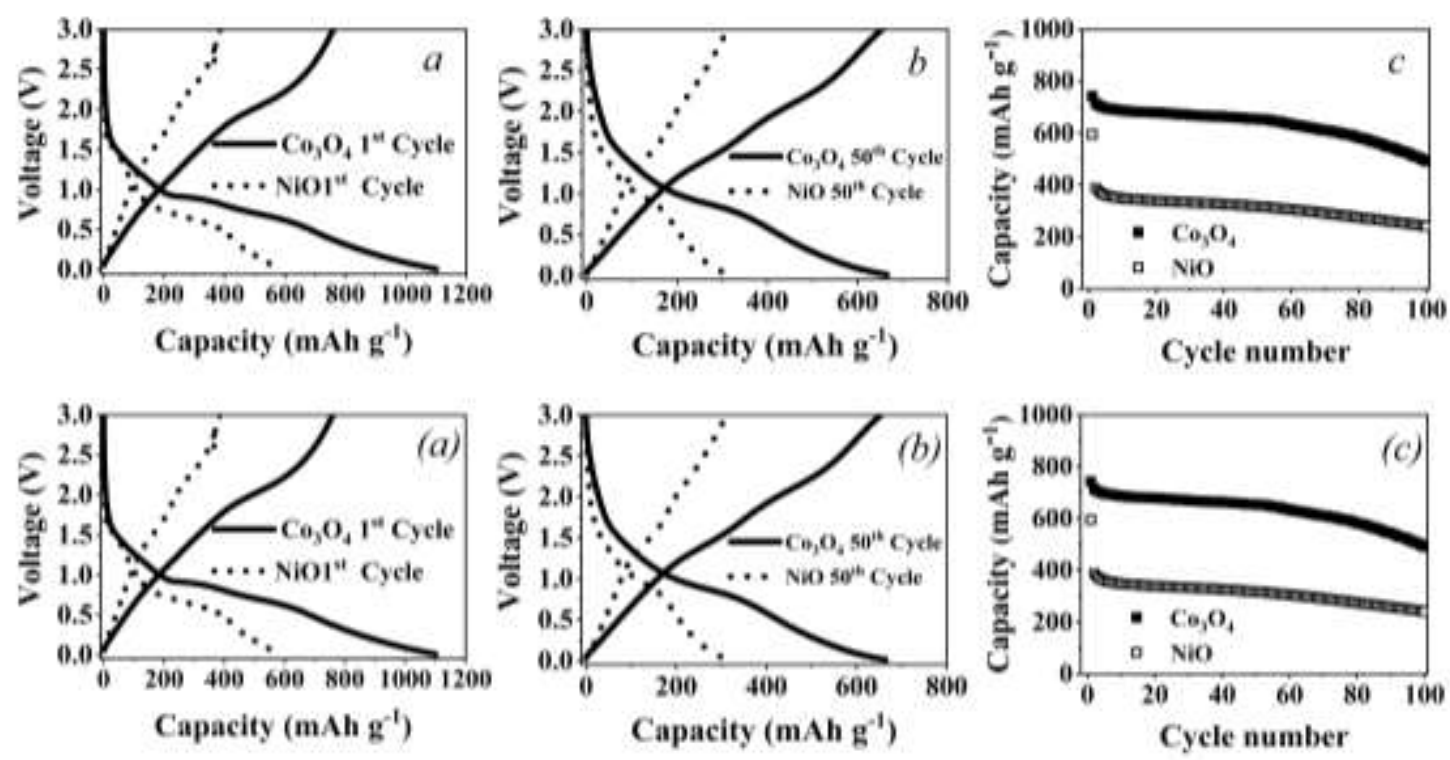

Fig. 4. Voltage signature of the 1 st cycle (a) and of the 50th cycle (b) of the galvanostatic cycling test of the $\mathrm{Li} / \mathrm{LP} 30 / \mathrm{NiO}$ (dotted line) and of the $\mathrm{Li} / \mathrm{LP} 30 / \mathrm{Co}_{3} \mathrm{O}_{4}$ (straight line) cells. (c) Cycling behavior of the $\mathrm{Li} / \mathrm{LP} 30 / \mathrm{NiO}$ (white) and of the $\mathrm{Li} / \mathrm{LP} 30 / \mathrm{Co}_{3} \mathrm{O}_{4}$ (black) cells (c).

Upon charge the formed $\mathrm{Co}$ is reversibly oxidized to $\beta-\mathrm{CoO}$ according to the following reactions [63]:

First discharge: $\mathrm{Co}_{3} \mathrm{O}_{4}+\mathrm{Li}^{+}+\mathrm{e}^{-} \rightleftharpoons 3 \mathrm{Co}+\mathrm{LiO}_{x}$

First charge: $\mathrm{Co}+\mathrm{LiO}_{x} \rightleftharpoons \beta-\mathrm{CoO}+\mathrm{Li}^{+}+\mathrm{e}^{-}$

Following cycles: $\beta-\mathrm{CoO}+\mathrm{Li}^{+}+\mathrm{e}^{-} \rightleftharpoons \mathrm{Co}+\mathrm{LiO}_{x}$ 
Accordingly, the estimated maximum achievable capacity is $890 \mathrm{mAh} \mathrm{g}^{-1}$. During the first cycle the coulombic efficiency is about the $65 \%$ due to the irreversible reaction of solid-electrolyte interface (SEI) formation at the surface of the anode [64].

$\mathrm{NiO}$ electrode shows a similar behavior with a first plateau at about $0.9 \mathrm{~V}$ associates to the reduction of $\mathrm{NiO}$ to $\mathrm{Ni}$ according to the following reaction [21]:

$\mathrm{NiO}+\mathrm{Li}^{+}+\mathrm{e}^{-} \rightleftharpoons \mathrm{Ni}+\mathrm{LiO}_{x}$

According to the electrochemical reaction, a maximum capacity of $717 \mathrm{mAh} \mathrm{g}^{-1}$ can be reached. As in $\mathrm{Co}_{3} \mathrm{O}_{4}$ case, the reaction is reversible with an efficiency in the first cycle of about the $60 \%$ due to SEI formation at the surface of the electrode.

In Fig. 4(b), the voltage profiles for the $50^{\text {th }}$ cycle of $\mathrm{Co}_{3} \mathrm{O}_{4}$ (straight line) and $\mathrm{NiO}$ (dotted line) are reported, showing that both materials are characterized by a coulombic efficiency close to the $98 \%$ at the steady state cycling condition. Fig. 4(c) reports the comparison of the cycling behavior of the two investigated anode materials, evidencing that $\mathrm{Co}_{3} \mathrm{O}_{4}$ was characterized by a higher delivered capacity $\left(700 \mathrm{mAh} \mathrm{g}^{-1}\right)$ with respect to $\mathrm{NiO}\left(400 \mathrm{mAh} \mathrm{g}^{-1}\right)$. The reported capacities are referred to the mass of the metal oxide plus graphite. The single contribution of graphite was estimated in literature about $400 \mathrm{mAh} \mathrm{g}^{-1}$ [21]. Considering the weight ratio of the active material (oxide:graphite $=60: 40$ ), $\mathrm{Co}_{3} \mathrm{O}_{4}$ delivers a capacity of $900 \mathrm{mAh} \mathrm{g}^{-1}$, which is close to the theoretical one. As for $\mathrm{NiO}$, the overall capacity of $400 \mathrm{mAh} \mathrm{g}^{-1}$ was found including the contribution of graphite. As such, $\mathrm{NiO}$ denoted a small individual contribution if compared to the theoretical one, probably limited by impurities and non-stoichiometric lattice.

Both materials showed a relatively good cycling stability. In particular, $\mathrm{Co}_{3} \mathrm{O}_{4}$ denoted a decrease after the $55^{\text {th }}$ cycle. This kind of behavior is most likely associated to the poor quality of SEI formed at the anode interface, thus leading to an increase of the cell impedance during cycling and the consequent capacity decay. In order to mitigate this effect, different electrolyte additives have been evaluated with the best performing anode material $\left(\mathrm{Co}_{3} \mathrm{O}_{4}\right)$. The results reported in Fig. 5 , clearly evidenced the impact of using these additives on the electrochemical behavior of $\mathrm{Co}_{3} \mathrm{O}_{4}$ anode. VC and LiBOB additives evidenced the best improvement in the cycling stability, with a superior capacity for the cell employing $\mathrm{VC}$ additive. The lower capacity of the cell employing LiBOB electrolyte can be most likely ascribed to the elevated thickness of the SEI formed, thus limiting the kinetic of the electrochemical process. A further advantage of using VC is the higher coulombic efficiency with respect to other additives, confirming the improved quality of SEI interface obtained with VC.

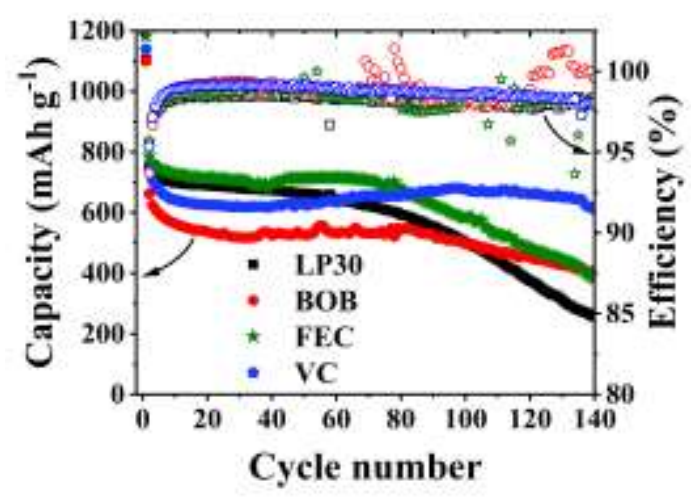

Fig. 5. Cycling behavior of the galvanostatic cycling test performed on $\mathrm{Li} / \mathrm{LP} 30+2 \%$ additive $/ \mathrm{Co}_{3} \mathrm{O}_{4}$ cells. In black the pristine electrolyte, in blue the $\mathrm{VC}$ added electrolyte, in red the LiBOB added electrolyte and in green the FEC added electrolyte. 
Finally, the investigated anode material was employed for assembling a lithium-ion cell by coupling the developed anode with an NCA cathode material. Fig. 6 reports the voltage profile (Fig. 6a) and cycling behavior (Fig. 6b) of this lithium-ion cell. $\mathrm{Co}_{3} \mathrm{O}_{4} / \mathrm{NCA}$ cell showed an average voltage of $2.8 \mathrm{~V}$, with a delivered capacity of about $190 \mathrm{mAh} \mathrm{g}^{-1}$, thus leading to an energy density (in respect to the cathode mass) of $530 \mathrm{Wh} \mathrm{kg}^{-1}$. To have an estimation of the possible practical capacity of the system we can apply the rule of thumb of dividing by three the theoretical energy density, to take into account the weight of the anode, electrolyte and the other cell component [65]. Employing this procedure, we can estimate that the developed cell can have a practical energy density of about $180 \mathrm{Wh} \mathrm{kg}^{-1}$, which is competitive with the commercial Li-ion battery. Fig. 6 (b) reports the cycling behavior of $\mathrm{Co}_{3} \mathrm{O}_{4} / \mathrm{NCA}$ lithium-ion cell revealing a stable cycling behavior for the 20 cycles of the test. The obtained results demonstrate a proof concept, i.e. the possibility of using the metal oxide recycled from battery for the production of new electrode materials.
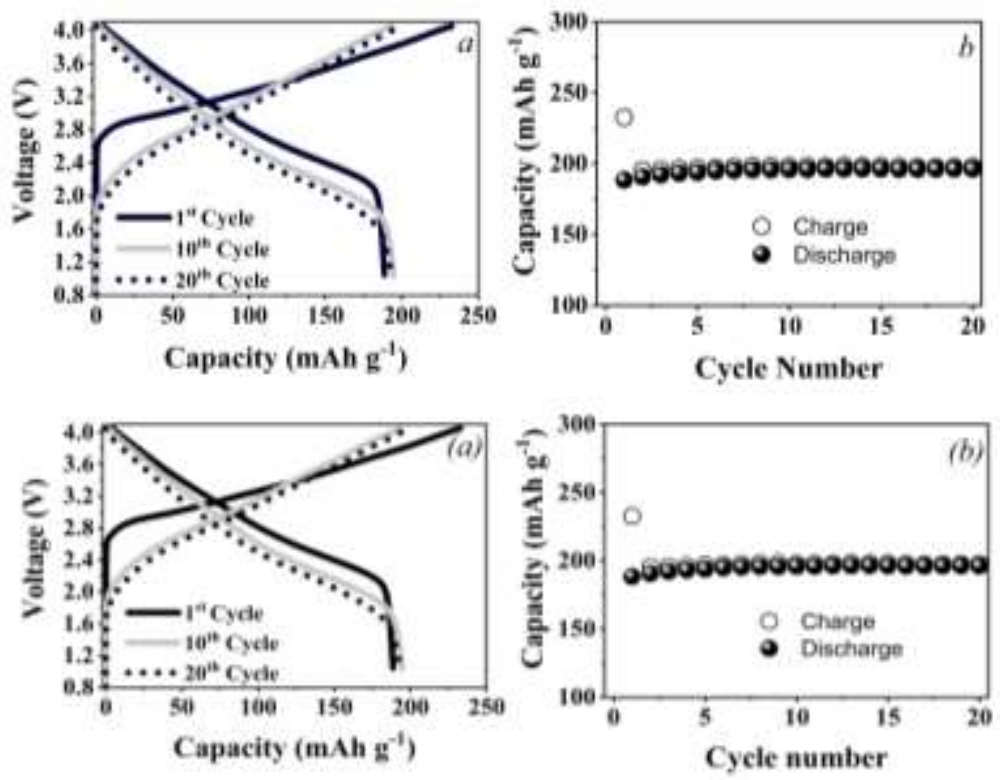

Fig. 6. Voltage signature (a) and cycling behavior (b) of the $\mathrm{Co}_{3} \mathrm{O}_{4} / \mathrm{LP} 30+2 \%$ VC/NCA lithium ion cell.

\section{Conclusions}

In this work, the operating conditions, and the product characterization for an enhanced hydrometallurgical recycling process of black mass from LIB are reported. The process was optimized considering the black mass composition obtained from an automated pre-treatment process at pilot scale. About 30\% of the initial weight of the LIB waste was recovered by these primary treatments as $\mathrm{Cu}, \mathrm{Al}$, and steel scraps. The hydrometallurgical treatment of the black mass allowed the recovery of additional fractions of waste: $15 \%-16 \%$ of LIB wastes as graphite, $10 \%-$ $12 \%$ as cobalt products, $1 \%-3 \%$ as nickel hydroxide/oxide and $1 \%-2 \%$ as lithium carbonate. Then, more than $50 \%$ of LIB waste mass can be recovered by the proposed combination of physical pretreatment and hydrometallurgical process presented in this work. Such recovery rate satisfies the target established in the EU directive 2006/66/EC for batteries and accumulators [66]. Characterization tests here reported showed that graphite, $\mathrm{CoC}_{2} \mathrm{O}_{4} \cdot 2 \mathrm{H}_{2} \mathrm{O}$ and $\mathrm{Li}_{2} \mathrm{CO}_{3}$ obtained in this process widely satisfy the market standards.

Moreover, the insight for valorization of LIB process by-products and wastes evidenced the real chance to obtain supplementary products with commercial grade, as in the case of $\mathrm{Na}_{2} \mathrm{SO}_{4}$, and 
added-value compounds, as in the case of Mn-Co magnetic nano-ferrites. Potential innovative application of mixed oxides $\left(\mathrm{Co}_{3} \mathrm{O}_{4}\right.$ and $\left.\mathrm{NiO}\right)$ as conversion anodes in advanced $\mathrm{LIB}$ was proven denoting promising performances.

Regarding the potential scale up of the process, it involves various stages but is made up of proven technologies and consolidated chemical operations, already widely used in mining and recycling industry. In addition, the proposed configuration of the hydrometallurgical section is flexible to the expected variations of the LIB compositions in the coming years. In fact, the unit operations can be included or excluded from the primary line of treatment according to the needs, since each stage (excluding leaching) targets the purification of one single class of metals.

Nevertheless, another possible development of the process can be towards the elimination of some operations of purification applying a new point of view in order to make feasible the recycling of

such wastes. New processes can be optimised aiming at the production of innovative materials exploiting the heterogeneity of black mass as an advantage instead of a limit. For instance, considering the recent diffusion of mixed oxides for the production of Li ion cathodes (such as NCM and NCA) the black mass containing all these metals can be used for the direct production after leaching of the same mixed oxides without separation of the single metals. In this way, the process could be easier with a lower number of steps by integrating extraction and product recovery.

According to the specific process here proposed, some of the operational parameters (e.g. O: A ratios of liquid-liquid separations and stripping, acid concentration for stripping phase) and reagent dosage could be further optimized to have an economically viable process. Even though preliminary mass balances have been defined, the economical assessment was beyond the scope of this work, which aimed to prove the technical feasibility of the hydrometallurgical process, the necessity of process intensification for secondary streams and by-products, and the commitment towards zero waste and closed loop processes for LIB recycling.

\section{Acknowledgments}

Part of the research activities reported in this work were co-financed within European project HydroWEEE Demo "For Innovative Hydrometallurgical Processes To Recover Metals From WEEE Including Lamps And Batteries”: Demonstration (Grant agreement No. 308549).

\section{References}

[1] L. Yun, D. Linh, L. Shui, X. Peng, A. Garg, M. Loan, P. Le, S. Asghari, Resour. Conserv. Recycl. 136 (2018) 198-208.

[2] W. Lv, Z. Wang, H. Cao, Y. Sun, Y. Zhang, Z. Sun, ACS Sustain. Chem. Eng. 6 (2018) 1504-1521.

[3] X. Zhang, L. Li, E. Fan, Q. Xue, Y. Bian, F. Wu, R. Chen, Chem. Soc. Rev. 47 (2018) 72397302.

[4] H. Nie, L. Xu, D. Song, J. Song, X. Shi, X. Wang, L. Zhang, Z. Yuan, Green Chem. 17 (2015) 1276-1280.

[5] J. Li, G. Wang, Z. Xu, Waste Manag. 52 (2015) 221-227.

[6] X. Wang, G. Gaustad, C.W. Babbitt, Waste Manag. 51 (2016) 204-213.

[7] J. Yu, Y. He, Z. Ge, H. Li, W. Xie, S. Wang, Sep. Purif. Technol. 190 (2018) 45-52.

[8] T. Ellis, A. Mirza, Www.Researchgate.Net (2014) 1-33.

[9] Y. Liu, D. Mu, Y. Dai, Q. Ma, R. Zheng, C. Dai, Int. J. Electrochem. Sci. 11 (2016) 7594- 
7604.

[10] A.J. Da Costa, J.F. Matos, A.M. Bernardes, I.L. Müller, Int. J. Miner. Process. 145 (2015) $77-82$.

[11] Grand View Research, Www.Grandviewresearch.Com/Industry-Analysis/Lithium-IonBattery-Market (2017).

[12] H. Ku, Y. Jung, M. Jo, S. Park, S. Kim, D. Yang, K. Rhee, E.M. An, J. Sohn, K. Kwon, J. Hazard. Mater. 313 (2016) 138-146.

[13] X. Chen, Y. Chen, T. Zhou, D. Liu, H. Hu, S. Fan, Waste Manag. 38 (2015) 349-356.

[14] X. Chen, H. Ma, C. Luo, T. Zhou, J. Hazard. Mater. 326 (2017) 77-86.

[15] E. Gratz, Q. Sa, D. Apelian, Y. Wang, J. Power Sources 262 (2014) 255-262.

[16] L. Li, Y. Bian, X. Zhang, Y. Guan, E. Fan, F. Wu, R. Chen, Waste Manag. 71 (2018) 362 371.

[17] V.C.B. Pegoretti, P.V.M. Dixini, P.C. Smecellato, S.R. Biaggio, M.B.J.G. Freitas, Mater. Res. Bull. 86 (2017) 5-9.

[18] J. Tarascon, P. Poizot, S. Laruelle, S. Grugeon, L. Dupont, Nature 407 (2000) 496-499.

[19] J. Ming, J.-B. Park, Y.-K. Sun, ACS Appl. Mater. Interfaces 5 (2013) 2133-6.

[20] L. Zhuo, Y. Wu, J. Ming, L. Wang, Y. Yu, X. Zhang, F. Zhao, J. Mater. Chem. A 1 (2013) $1141-1147$.

[21] R. Verrelli, J. Hassoun, ChemElectroChem 2 (2015) 988-994.

[22] G.A.G.A. Elia, S. Panero, A. Savoini, B. Scrosati, J. Hassoun, Electrochim. Acta 90 (2013) 690-694.

[23] F. Pagnanelli, E. Moscardini, P. Altimari, T. Abo Atia, L. Toro, Waste Manag. 51 (2016) 214-221.

[24] F. Pagnanelli, E. Moscardini, P. Altimari, T. Abo Atia, L. Toro, Waste Manag. 60 (2017) 706-715.

[25] G. Granata, F. Pagnanelli, E. Moscardini, Z. Takacova, T. Havlik, L. Toro, J. Power Sources 212 (2012) 205-211.

[26] J. Yang, H. Liu, W.N. Martens, R.L. Frost, J. Phys. Chem. C 114 (2010) 111-119.

[27] E.M.S. Barbieri, E.P.C. Lima, M.F.F. Lelis, M.B.J.G. Freitas, J. Power Sources 270 (2014) $158-165$.

[28] D. Wang, C. Song, Z. Hu, X. Fu, J. Phys. Chem. B 109 (2005) 1125-1129.

[29] C. Zhu, Y. Dong, Z. Yun, Y. Hao, C. Wang, N. Dong, W. Li, Hydrometallurgy 149 (2014) 143-147.

[30] T.A. Atia, P. Altimari, E. Moscardini, I. Pettiti, L. Toro, F. Pagnanelli, Chem. Eng. Trans. 47 (2016) 151-156.

[31] R. Verrelli, J. Hassoun, J. Power Sources 299 (2015) 611-616.

[32] X. Chen, C. Luo, J. Zhang, J. Kong, T. Zhou, ACS Sustain. Chem. Eng. 3 (2015) 3104-3113.

[33] P. Meshram, Abhilash, B.D. Pandey, T.R. Mankhand, H. Deveci, Jom 68 (2016) 2613-2623.

[34] G.P. Nayaka, K.V. Pai, J. Manjanna, S.J. Keny, Waste Manag. 51 (2016) 234-238.

[35] F. Pagnanelli, E. Moscardini, G. Granata, S. Cerbelli, L. Agosta, A. Fieramosca, L. Toro, J. Ind. Eng. Chem. 20 (2014) 3201-3207.

[36] L. Poláková, H. Beneš, P. Ecorchard, E. Pavlová, Z. Sedláková, J. Kredatusová, V. Štengl, RSC Adv. 6 (2016) 353-357.

[37] D.M. Stefanescu, G. Alonso, P. Larrañaga, E. De La Fuente, R. Suarez, Acta Mater. 107 (2016) 102-126. 
[38] H. Badenhorst, Carbon N. Y. 66 (2014) 674-690.

[39] Y. Guo, F. Li, H. Zhu, G. Li, J. Huang, W. He, Waste Manag. 51 (2016) 227-233.

[40] J.E.C. Sabisch, A. Anapolsky, G. Liu, A.M. Minor, Resour. Conserv. Recycl. 129 (2018) 129-134.

[41] B. Moradi, G.G. Botte, J. Appl. Electrochem. 46 (2016) 123-148.

[42] F. Schipper, D. Aurbach, Russ. J. Electrochem. 52 (2016) 1095-1121.

[43] M. Rajamathi, P.V. Kamath, R. Seshadri, Mater. Res. Bull. 35 (2000) 271-278.

[44] G.G.C. Arizaga, K.G. Satyanarayana, F. Wypych, Solid State Ionics 178 (2007) 1143-1162.

[45] P. Meshram, B.D. Pandey, T.R. Mankhand, Chem. Eng. J. 281 (2015) 418-427.

[46] C. Lee, C. Lee, Korean J. Chem. Eng. 22 (2005) 712-716.

[47] K.-W. Nam, W.-S. Yoon, K.-B. Kim, Electrochim. Acta 47 (2002) 3201-3209.

[48] Z. Wu, X.L. Huang, Z.L. Wang, J.J. Xu, H.G. Wang, X.B. Zhang, Sci. Rep. 4 (2014).

[49] D.S. Hall, D.J. Lockwood, C. Bock, B.R. MacDougall, Proc. R. Soc. A Math. Phys. Eng. Sci. 471 (2014) 20140792-20140792.

[50] H. Arai, S. Okada, Y. Sakurai, J. Yamaki, Solid State Ionics 109 (1998) 295-302.

[51] L. Pastero, F.R. Massaro, D. Aquilano, Cryst. Growth Des. 7 (2007) 2749-2755.

[52] N. Shahidzadeh-Bonn, S. Rafai, D. Bonn, G. Wegdam, Langmuir 24 (2008) 8599-8605.

[53] C. Rodriguez-Navarro, E. Doehne, E. Sebastian, Cem. Concr. Res. 30 (2000) 1527-1534.

[54] Z. Yao, H. Wu, Y. Li, J. Wang, J. Zhang, M. Zhang, Y. Guo, P. Wang, Energy Environ. Sci. 8 (2015) 3192-3197.

[55] M. Paleologou, R.M.B. , A. Thibault, P-Y. Wong, R. Thompson, Sep. Purif. Technol. 11 (1997) 159-171.

[56] J.D. Genders, D. Hartsough, Electrodialysis of Multivalent Metal Salts, US 6,712,946 B2, 2004.

[57] J. Ortiz-Landeros, C. Gómez-Yáñez, R. López-Juárez, I. Dávalos-Velasco, H. Pfeiffer, J. Adv. Ceram. 1 (2012) 204-220.

[58] M.M. Rashad, R.M. Mohamed, M.A. Ibrahim, L.F.M. Ismail, E.A. Abdel-Aal, Adv. Powder Technol. 23 (2012) 315-323.

[59] M. Goodarz Naseri, E. Bin Saion, H.A. Ahangar, M. Hashim, A.H. Shaari, J. Magn. Magn. Mater. 323 (2011) 1745-1749.

[60] I. Sharifi, H. Shokrollahi, M.M. Doroodmand, R. Safi, J. Magn. Magn. Mater. 324 (2012) 1854-1861.

[61] N. Sezgin, M. Sahin, A. Yalcin, Y. Koseoglu, Ekoloji 96 (2013) 89-96.

[62] S.H. Yu, S.H. Lee, D.J. Lee, Y.E. Sung, T. Hyeon, Small 12 (2016) 2146-2172.

[63] Y. Li, B. Tan, Y. Wu, Nano Lett. 8 (2008) 265-270.

[64] E. Peled, D. Golodnitsky, G. Ardel, V. Eshkenazy, Electrochim. Acta 40 (1995) 2197-2204.

[65] P.G. Bruce, S.A. Freunberger, L.J. Hardwick, J.-M. Tarascon, Nat. Mater. 11 (2012) 172172.

[66] EUR-Lex, Off. J. Eur. Union L 266 (2006) 1-14.

\section{Graphical abstract}




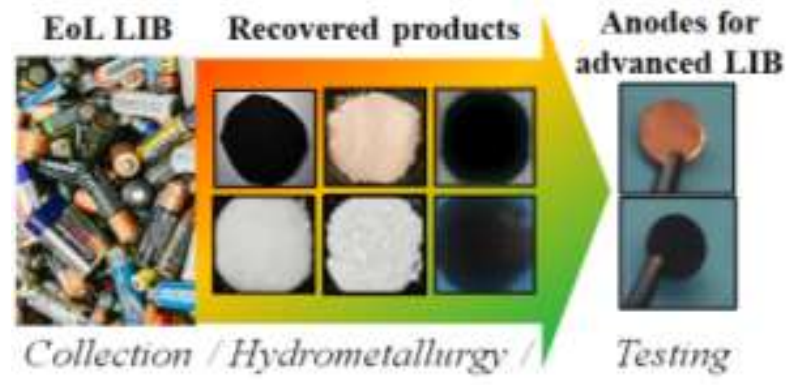

End of life LIB were treated by mechanical and hydrometallurgical operations for integral recovery of all materials and reuse of $\mathrm{Ni}$ and $\mathrm{Co}$ oxides as anodes in advanced conversion LIB. 